\title{
Frequent downregulation of $14-3-3 \sigma$ protein and hypermethylation of $14-3-3 \sigma$ gene in salivary gland adenoid cystic carcinoma
}

\author{
D Uchida ${ }^{*}$, , N-M Begum', A Almofti', H Kawamata ${ }^{2}$, H Yoshida' and M Sato' \\ 'Second Department of Oral and Maxillofacial Surgery, Tokushima University School of Dentistry, 3-1 8-1 5 Kuramoto, Tokushima 770-8504, Japan; \\ ${ }^{2}$ Department of Surgical and Molecular Pathology, Dokkyo University School of Medicine, 880 Kita-kobayashi, Mibu, Shimo-tsuga, Tochigi 32 I-0293, \\ Japan
}

\begin{abstract}
14-3-3 $\sigma$, a target gene of the p53 tumour suppressor protein, has been shown to regulate the cell cycle at the G2/M checkpoint. Recent studies have demonstrated that 14-3-3 $\sigma$ is downregulated by hypermethylation of the CpG island in several types of cancer. In this study, we investigated the expression and methylation status of 14-3-3 $\sigma$ in human salivary gland adenoid cystic carcinoma (ACC) and mucoepidermoid carcinoma (MEC). Immunohistochemical analysis revealed that the positive expression rate of I4-3-3 $\sigma$ in ACC (one out of 14) was markedly lower than that in MEC (ten out of 10). Since most of the ACCs carried the wild-type p53 protein, downregulation of 14-3-3 $\sigma$ in ACC may not be due to the dysfunction of p53 pathway. Microdissection-methylationspecific PCR revealed that frequent hypermethylation of the 14-3-3 $\sigma$ gene was observed in ACC when compared to that in MEC. In cultured-ACC cells, we confirmed the downregulation of 14-3-3 $\sigma$ via hemimethylation of the gene by sequencing analysis after sodium bisulphite treatment. Furthermore, re-expression of 14-3-3 $\sigma$ in the ACC cells was induced by the treatment with DNA demethylating agent, 5-aza-2'-deoxycytidine. Irradiation apparently induced the enhanced expression of I4-3-3 $\sigma$ and G2/M arrest in normal salivary gland cells; however, in the ACC cells, neither induction of 14-3-3 $\sigma$ nor G2/M arrest was induced by irradiation. These results suggest that downregulation of 14-3-3 $\sigma$ might play critical roles in the neoplastic development and radiosensitivity of ACC.
\end{abstract}

British Journal of Cancer (2004) 91, I I3 I- | |38. doi: I0.1038/sj.bjc.6602004 www.bjcancer.com

Published online 3 August 2004

(c) 2004 Cancer Research UK

Keywords: adenoid cystic carcinoma; mucoepidermoid carcinoma; 14-3-3 $\sigma$; p53; methylation

Salivary gland cancers (SGCs) are somewhat rare diseases, comprising about $10 \%$ of the head and neck cancers (Speight and Barrett, 2002). Estimated annual incidence of this diseases is approximately 400 cases in Japan (Ajiki et al, 2001); however, it is well known that prognosis of SGCs is considerably poor (Bensadoun et al, 2001). Salivary gland cancers are divided histologically into low-grade and high-grade malignancies (Seifert and Sobin, 1992). High-grade SGCs, such as adenoid cystic carcinoma (ACC) and mucoepidermoid carcinoma (MEC) (Batsakis, 1979), invade the surrounding tissues (including nerve, muscle, and cutaneous tissue), and frequently metastasise to the regional lymph nodes and distant organs, such as lungs and brain. Adenoid cystic carcinoma and MEC, the most common malignancies of the salivary glands, are clinically and pathologically different. Adenoid cystic carcinoma occurs frequently in the minor salivary glands $(59 \%$ of total malignant tumours in minor salivary gland; Le et al, 1999). On the other hands, MEC occurs frequently in the major salivary glands $51 \%$ of total malignant tumours in

*Correspondence: Dr D Uchida; E-mail: daisuke@dent.tokushima-u.ac.jp Received 13 November 2003; revised II May 2004; accepted 20 May 2004; published online 3 August 2004 major salivary gland; Pinkston and Cole, 1999). Although radical surgery has been the main therapy for these cancers, irradiation has often been recommended for the treatment of the advanced SGCs. However, the radiosensitivity is reported to be quite different in ACC and MEC. Combination radical surgery with radiotherapy in ACC has led to superior results in many studies (Simpson et al, 1984; Vikram et al, 1984; Miglianico et al, 1987; Garden et al, 1995; Parsons et al, 1996), but in MEC such combination treatment is generally less effective (Nascimento et al, 1986; Grenman et al, 1992). These findings suggest that cell cyclerelated gene(s) at the G2 checkpoint might play important roles in the difference in radiosensitivity between these cancers, since the G2-residing cells are normally more sensitive to irradiation. However, alteration of G2 cell cycle regulators such as p53 is reported to be infrequent in SGCs (Papadaki et al, 1996; Tsubochi et al, 2000; Kiyoshima et al, 2001). Thus, it is possible that novel G2 cell cycle regulator(s) contribute to the different radiosensitivity in SGCs.

14-3-3 $\sigma$ (also called stratifin) was first identified as a gene expressed specifically in the differentiated squamous epithelium, and loss of 14-3-3 $\sigma$ immortalised squamous epithelium (Leffers et al, 1993). A subsequent study showed that 14-3-3 $\sigma$ was strongly induced by $\gamma$-irradiation and other DNA-damaging agents via a 
p53-dependent pathway (Hermeking et al, 1997). Moreover, Chan et al (1999) reported that 14-3-3 $\sigma$-deficient cells were rapidly killed by ionizing radiation through a process known as mitotic catastrophe, which was associated with a failure of the cells to sequester cyclin $\mathrm{B} / \mathrm{CDC} 2$ complex from the nucleus. More recently, it was shown that the expression of 14-3-3 $\sigma$ was frequently lost in several types of cancers due to hypermethylation of the gene (Ferguson et al, 2000; Iwata et al, 2000; Suzuki et al, 2000; Gasco et al, 2002a, b; Osada et al, 2002). These findings indicate that 14-3$3 \sigma$ plays diverse roles not only in the radiosensitivity of the cells but also in tumorigenesis of several cancer, including SGCs.

In this study, we investigated the expression of 14-3-3 $\sigma$ protein and methylation status of 14-3-3 $\sigma$ gene in ACC and MEC. Then, we report for the first time that 14-3-3 $\sigma$ in salivary gland ACC is frequently downregulated due to the hypermethylation of the gene.

\section{MATERIALS AND METHODS}

\section{Immunohistochemistry (IHC)}

Salivary gland cancer tissues surgically obtained at the Tokushima University School of Dentistry from 1982 to 2002 were routinely fixed with formalin and embedded in paraffin. Before staining, sections $4 \mu \mathrm{m}$ thick mounted on poly-L-lysine-coated slides were deparaffinised with xylene and rehydrated in graded ethanol. For the purpose of antigen retrieval, sections were incubated in Target retrieval solution (DAKO, Carpinteria, CA, USA) at $95^{\circ} \mathrm{C}$ for $20 \mathrm{~min}$. After blocking with $3 \%$ horse serum in phosphate-buffered saline, samples were incubated at room temperature for $1 \mathrm{~h}$ with the goat polyclonal 14-3-3 $\sigma$ antibody (Santa Cruz Biotechnology, Santa Cruz, CA, USA) diluted to $1: 100$ and monoclonal p53 antibody (DO-7; DAKO) diluted to $1: 100$ with the blocking solution, and for the subsequent steps the avidin-biotinperoxidase method was performed using a Vectastain $\mathrm{ABC}$ kit (Vector, Burlingame, CA, USA). We defined the cases, in which over $25 \%$ of the cancer cells were stained for $14-3-3 \sigma$ or p53, as IHC-positive $(+)$. When the ratio of the positive-stained cells did not reach $25 \%$, or the cells were not stained for $14-3-3 \sigma$ or p53, we defined these cases as IHC-negative (-).

\section{Methylation-specific PCR (MSP)}

The cancer nests in the five $10 \mu \mathrm{m}$-thick paraffin sections were dissected under the stereomicroscopy with a 24-gauge needle and mineral oil. DNA was prepared using an EX-WAX DNA Extraction kit (Serologicals Corporation, Norcross, GA, USA) according to the manufacturer's instructions. In all, $1 \mu \mathrm{g}$ of genomic DNA was subjected to sodium bisulphite modification by a CpGenome DNA modification kit (Serologicals Corporation), and then MSP was performed by using a primer set that covered four CG dinucleotides of 14-3-3 $\sigma$ DNA as described previously (Ferguson et al, $2000)$. For the $p 16^{I N K 4 A}$ gene, PCR was performed under the same conditions as described by Herman et al (1996). Densitometric analysis of the data was carried out by NIH imaging software (ver. 1.63). Methylation index was calculated as follows: the density of methylated band was divided by that of unmethylated band.

\section{Cell lines and culture}

Adenoid cystic carcinoma cell lines, ACCS and ACCY (Shirasuna et al, 1990), were kindly provided by Drs Hiroaki Ishibashi and Kanemitsu Shirasuna (Second Department of Oral and Maxillofacial Surgery, Kyusyu University School of Dentistry). Normal salivary gland cells (SG1 and SG2) were independently cultured from normal human submandibular gland tissue. TYS (Yanagawa et al, 1986) and HSG (Shirasuna et al, 1981) were salivary adenosquamous cell carcinoma cells and neoplastic human salivary intercalated duct cells, respectively. All the cells except normal salivary gland cells were maintained in DMEM supplemented with $10 \% \mathrm{FCS}, 100 \mu \mathrm{g} \mathrm{ml}^{-1}$ streptomycin, and $100 \mathrm{U} \mathrm{ml}^{-1}$ penicillin in a humidified atmosphere of $95 \%$ air and $5 \% \mathrm{CO}_{2}$ at $37^{\circ} \mathrm{C}$. Salivary gland cells were maintained in Keratinocyte-SFM (Invitrogen, Carlsbad, CA, USA) and antibiotics.

\section{PCR - single-strand conformation polymorphism (SSCP)}

Exons 5-8 of the $p 53$ gene were examined for mutations by PCR SSCP analysis. Genomic DNA was amplified by PCR with four sets of primers. Primers for exon 5 were as follows: 5R, $5^{\prime}$ ACCCTGGGCAACCAGCCCTG- $3^{\prime}$ (sense); 5L, 5'-TTTATCTGTT CACTTGTGCCC-3' (antisense). Primers for exon 6 were 6R, $5^{\prime}$ CTCCCAGAGACCCCAGTTGC-3' (sense); 6L, 5'-TCAGATAGC GATGTGAGCAG-3' (anti-sense). Primers for exon 7 were 7R, 5' CAGTGTGCAGGGTGGCAAGT-3' (sense); 7L, 5'-GCCACAGGTCT CCCCAAGGC- $3^{\prime}$ (anti-sence). Primers for exon 8 were $8 \mathrm{R}, 5^{\prime}$ CCACCGCTTCTTGTCCTGCT-3' (sense); 8L, $5^{\prime}$-GACCTGATTTCC TTACTGCC- $3^{\prime}$ (anti-sense). Each target sequence was amplified in a $20 \mu \mathrm{l}$ reaction volume containing $100 \mathrm{ng}$ genomic DNA, $0.2 \mu \mathrm{M}$ dNTPs, $0.5 \mu \mathrm{M}$ of each primer and $0.05 \mathrm{U}^{-1}$ Advantage DNA polymerase (BD Clontech, Palo Alto, CA, USA) using the hot-start method. PCR amplification consisted of an initial activation step of $95^{\circ} \mathrm{C}$ for $3 \mathrm{~min}$, followed by 40 cycles of $95^{\circ} \mathrm{C}$ for $1 \mathrm{~min}, 56$ or $58^{\circ} \mathrm{C}$ for $1 \mathrm{~min}$, and $72^{\circ} \mathrm{C}$ for $4 \mathrm{~min}$. PCR products were diluted two-fold with formamide dye solution, denatured at $95^{\circ} \mathrm{C}$ for $5 \mathrm{~min}$ and separated by electrophoresis on $12.5 \%$ polyacrylamide gels with $5 \%$ glycerol at constant temperature $\left(14^{\circ} \mathrm{C}\right)$. Gels were stained and visualised with a Silver Staining II kit (Bio-Rad Laboratories, Hercules, CA, USA).

\section{RNA preparation and Northern blot analysis}

Cells (ACCS, ACCY, TYS, HSG, and SG) grown in monolayers were harvested at early confluence. After $24 \mathrm{~h}$, RNA isolation was performed using TRIzol reagent (Invitrogen) according to manufacture's instructions. RT - PCR and Northern blotting were carried out as described previously (Kawamata et al, 1998). The probes consisted of a $278 \mathrm{bp}$ fragment of human 14-3-3 $\sigma$ cDNA amplified from SG cDNA. PCR for mutation analysis of $p 53 \mathrm{mRNA}$ was carried out under the following conditions: $95^{\circ} \mathrm{C}$ for $3 \mathrm{~min}$, followed by 30 cycles of $94^{\circ} \mathrm{C}$ for $1 \mathrm{~min}, 62^{\circ} \mathrm{C}$ for $45 \mathrm{~s}$, and $72^{\circ} \mathrm{C}$ for $1 \mathrm{~min}$, and a final extension at $72^{\circ} \mathrm{C}$ for $10 \mathrm{~min}$. Amplified fragments for the $p 53$ open reading frame were cloned by a TOPO TA cloning system (Invitrogen), and five independent clones were sequenced by an ALOKA DNA sequencer (ALOKA, Tokyo, Japan). The primers used were as follows: for 14-3-3 $\sigma, 5^{\prime}$-GTGT GTCCCCAGAGCCATGG- $3^{\prime}$ and 5'-ACCTTCTCCCGGTACTCA CG-3'; for p53, $5^{\prime}$-GGAATTCCGATGGAGGAGCCGCAGTCAG-3' and $5^{\prime}$-GCGTCGACTCAGTCTGAGTCAGGCCCTTC-3'.

\section{Western blotting}

Cells were seeded at a density of $1 \times 10^{5}$ cells per $60 \mathrm{~mm}$ culture dish. Next, the cells were lysed with a buffer containing $50 \mathrm{~mm}$ Tris- $\mathrm{HCl}$ ( $\mathrm{pH} 7.5$ ), $150 \mathrm{~mm} \mathrm{NaCl}, 1 \%$ Nonidet P-40, and a protease inhibitor cocktail tablet (Roche Molecular Biochemicals, Mannheim, Germany). After centrifugation, aliquots of the supernatant containing $30 \mu \mathrm{g}$ protein were analysed by $10 \%$ SDS - polyacrylamide gel electrophoresis. The separated proteins were transferred to a polyvinylidene difluoride membrane (Amersham Pharmacia Biotech., Uppsala, Sweden), and the membrane was incubated with primary antibodies against 14-3-3 $\sigma$, and $\beta$-actin (Sigma, St Louis, MO, USA), followed by horseradish peroxidaseconjugated secondary antibodies. Detection was then performed using an enhanced chemiluminescence kit (Amersham Pharmacia Biotech.). 
Sequencing analysis of 14-3-3 $\sigma$ gene after sodium bisulphite treatment

Genomic DNA was prepared by the SDS-proteinase K method, and then subjected to the sodium bisulphite modification. The DNA modification was performed by a CpGenome DNA modification kit (Serologicals Corporation) as described above. Bisulphiteconverted DNA was amplified, using primers that generated a 474-bp PCR product, as described previously (Ferguson et al, 2000). Amplified PCR products were cloned by using the TOPO TA cloning system, then DNA sequencing was performed using an ALOKA DNA sequencer. Five independent clones were sequenced for each cell line.

\section{Treatment of cells with 5-aza-2'-deoxycytidine}

Cells were seeded at a density of $2 \times 10^{6}$ cells $60 \mathrm{~mm}$ plate ${ }^{-1}$. After $24 \mathrm{~h}$, cells were treated with or without $5 \mu \mathrm{M} 5$-aza-2'-deoxycytidine (Sigma) for 3 days. Preparation of total RNA, protein, and RT PCR were performed under the conditions as described above.

\section{Irradiation of the cells}

Logarithmically growing cells (SG1 and ACCY) were exposed to Xray irradiation at $15 \mathrm{~Gy}(150 \mathrm{kVp}, 5 \mathrm{~mA}$; MBR-1505R2, Hitachi Medico, Tokyo, Japan). After 24, 48, and $72 \mathrm{~h}$, the cells were harvested, and then the cells were subjected to flow cytometric analysis or Western blotting.

\section{Flow cytometric analysis}

After irradiation, the cells were trypsinised and fixed with $70 \%$ cold ethanol. Then, the precipitates were incubated with propidium iodide (PI) $\left(40 \mu \mathrm{g} \mathrm{ml}^{-1}\right)$ and RNaseA $\left(100 \mu \mathrm{g} \mathrm{ml}^{-1}\right)$ for $30 \mathrm{~min}$ at $37^{\circ} \mathrm{C}$, and analysed with an EPICS flow cytometer (Coulter, San Jose, CA, USA).

\section{RESULTS}

\section{Expression of 14-3-3 $\sigma$ in SGCs}

We examined the expression of 14-3-3 $\sigma$ in 10 cases of normal salivary gland, 14 cases of ACC, and 10 cases of MEC. In several SGCs occurred at minor salivary gland, we could observe the normal gingival tissue in the surgically resected samples. We used normal gingival tissue as positive control for IHC of 14-3-3 $\sigma$. In normal gingival epithelial cells, 14-3-3 $\sigma$ was barely detectable in the basal layer, but was increased in the suprabasal layers (Figure 1A), as described by Dellambra et al (2000). In normal salivary gland, we found the positive staining of 14-3-3 $\sigma$ protein on the salivary duct cells and the mucous gland cells, but not in the myoethithelial cells (Figure 1B). In ACCs, expression of 14-3-3 $\sigma$ was hardly detected in the neoplastic myoepihtelial cells, but faintly in the neoplastic duct cells (Figure 1C and D). Only in one case of 11 ACCs, more than $20 \%$ of the cells (mainly in the neoplastic duct cells) were positive for 14-3-3 $\sigma$ (Figure was not shown, Table 1). However, in MECs, most of the cells in most of the cases showed positive staining for 14-3-3 $\sigma$ (Figure $1 \mathrm{E}$ and $\mathrm{F}$ ). We summarised the result of the IHC for 14-3-3 $\sigma$ in Table 1.

Mutational status of $\mathrm{p} 53$ and the relation of the expression pattern of 14-3-3 $\sigma$ with the p53 status in SGCs

$14-3-3 \sigma$ is also known as a cell cycle regulator of the G2 phase, and is a target gene of the tumour suppressor p53 protein. Therefore, mutational status of p53 in ACC and MEC was examined by IHC and PCR-SSCP. Immunohistochemical study revealed that strong staining of p53 protein was infrequent both in ACC (three out of

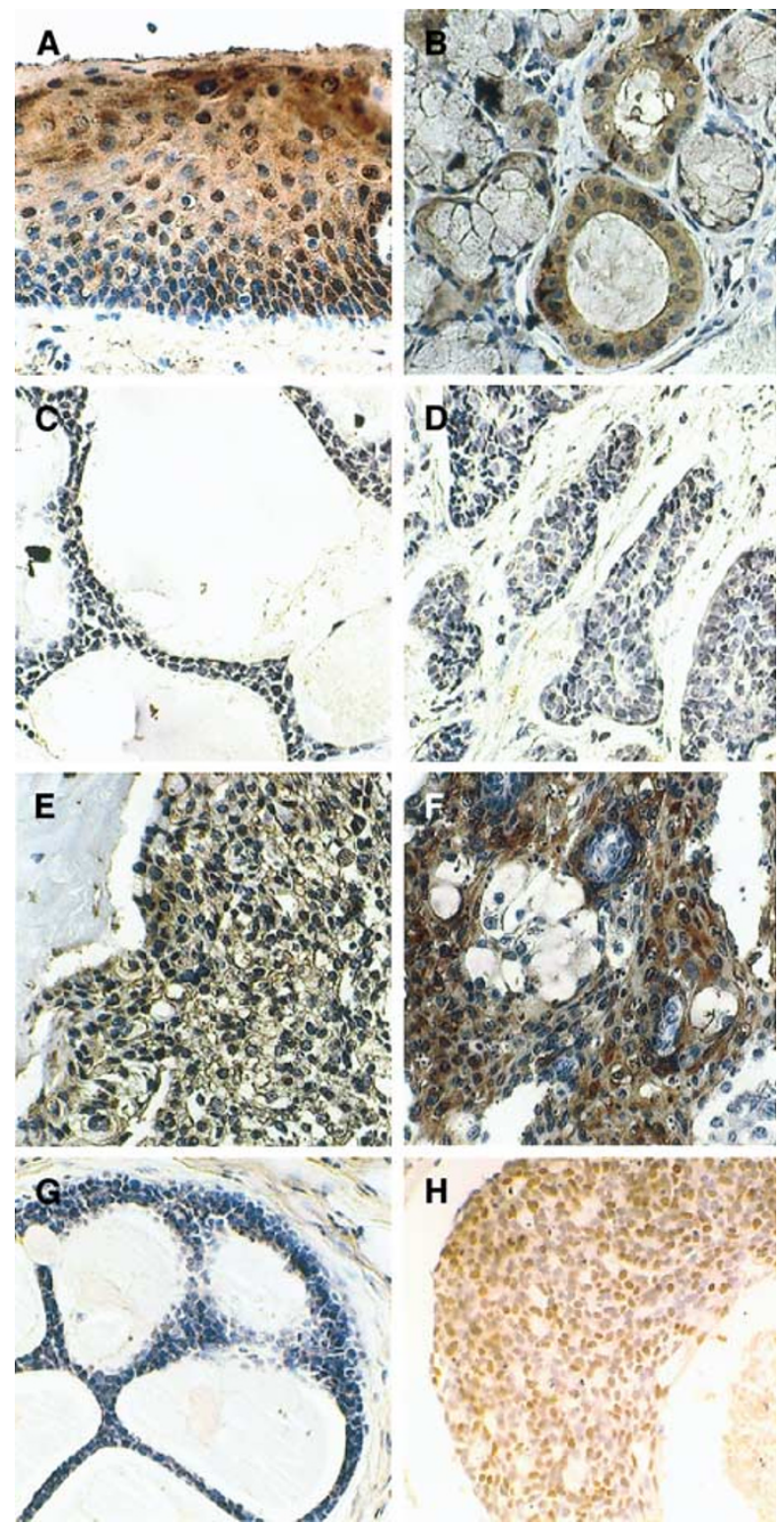

Figure I Immunohistochemical detection of | 4-3-3 $\sigma(\mathbf{A - F})$ and p53 $(\mathbf{G}, \mathbf{H})$. (A) Normal gingiva. (B) Normal salivary gland. (C) Adenoid cystic carcinoma with cribriform subtype. (D) Adenoid cystic carcinoma with solid subtype. (E, F) Mucoepidermoid carcinoma. (G) Adenoid cystic carcinoma with negative staining of p53. (H) Adenoid cystic carcinoma with positive staining of $\mathrm{p} 53$. Original magnification, $\times 400$

14) and MEC (two out of 10) (Figure 1G, H and Table 1). Moreover, as shown in Table 1, PCR - SSCP revealed that the mutation rate of the $p 53$ gene was increased - but still relatively low - in both ACC and MEC. There are no clear relationship between the expression pattern of 14-3-3 $\sigma$ and p53 status in both ACC and MEC (Table 1).

\section{Methylation status of 14-3-3 $\sigma$ gene and p16INK4A gene in SGCs}

It has been reported that downregulation of 14-3-3 $\sigma$ in several cancers was due to hypermethylation of the gene. Therefore, methylation status of the 14-3-3 $\sigma$ gene in ACC and MEC was examined by Microdissection-MSP method. The 14-3-3 $\sigma$ gene was frequently hypermethylated in ACC, but not in MEC (Figure 2A). In addition, densitometric analysis revealed that the 
Table I Summary of the IHC, MSP, and PCR-SSCP

\begin{tabular}{|c|c|c|c|c|c|c|}
\hline \multirow[b]{2}{*}{ No. } & \multirow[b]{2}{*}{ Primary site } & \multicolumn{2}{|c|}{ IHC } & \multicolumn{2}{|c|}{ Methylation index } & \multirow{2}{*}{$\frac{\text { PCR-SSCP }}{\text { p53 (exons 5-8) }}$} \\
\hline & & 14-3-3 $\sigma$ & p53 & $14-3-3 \sigma$ & pl6 & \\
\hline $\mathrm{ACC} 2$ & Submandibular gland & - & - & 1.40 & 0.31 & NC \\
\hline $\mathrm{ACC} 3$ & Floor of mouth & - & $+(\mathrm{N})$ & 0.45 & 0.31 & Exon 5 \\
\hline ACC4 & Floor of mouth & - & - & 3.26 & 1.75 & Exon 6 \\
\hline ACC5 & Tongue & - & - & 0.59 & 0.14 & NC \\
\hline ACC8 & Sublingual gland & - & - & 0.85 & 1.07 & Exon 6 \\
\hline ACC9 & Mandible & - & - & ND & ND & NC \\
\hline $\mathrm{ACCIO}$ & Floor of mouth & + & - & ND & ND & $\mathrm{NC}$ \\
\hline $\mathrm{ACCII}$ & Palate & - & - & ND & ND & ND \\
\hline $\mathrm{ACCl} 2$ & Palate & - & - & ND & ND & ND \\
\hline $\mathrm{ACCl} 3$ & Maxillary sinus & - & - & ND & ND & ND \\
\hline $\mathrm{ACCl} 4$ & Submandbular gland & - & - & ND & ND & ND \\
\hline MEC2 & Buccal mucosa & + & $+(\mathrm{C})$ & 0.41 & 0.37 & Exons $5-7^{\mathrm{a}}$ \\
\hline MEC3 & Buccal mucosa & + & - & 0.56 & 2.30 & NC \\
\hline MEC4 & Mandible & + & - & 0.11 & 0.67 & $\mathrm{NC}$ \\
\hline MEC5 & Palate & + & $+(\mathrm{C})$ & 0.80 & 0.11 & Exon 6 \\
\hline MEC6 & Palate & + & - & 0.44 & 0.21 & NC \\
\hline MEC7 & Maxillary sinus & + & - & 0.41 & 0.27 & NC \\
\hline MEC8 & Parotid gland & + & - & 0.34 & 0.25 & ND \\
\hline MEC9 & Mandible & + & - & ND & ND & ND \\
\hline MECIO & Submandibular gland & + & - & ND & ND & ND \\
\hline Mean & & & & 0.47 & 0.55 & \\
\hline Positive & & 10 & 2 & & & \\
\hline
\end{tabular}

- = negative staining; + = positive staining; $\mathrm{ND}=$ not determined; $(\mathrm{N})=$ staining in the nucleus; $(\mathrm{C})=$ staining in the cytoplasm. Methylation index was calculated as follows: the density of methylated band was divided by that of unmethylated band. NC = no change; $N D=$ not determined; $I H C=$ immunohistochemistry; $M S P=$ methylation-specific PCR; PCR-SSCP $=$ PCR-single-strand conformation polymorphism. ${ }^{a}$ Not amplified.

methylation index of ACC was significantly higher than that of MEC (one-way ANOVA, $P=0.0304$; Figure 2B). We also examined the methylation status of the $p 16^{I N K 4 A}$ gene, which has been shown to be frequently hypermethylated in several types of cancers (Herman et al, 1996; Rocco and Sidransky, 2001), and was coincidentally inactivated with 14-3-3 $\sigma$ in oral and vulval squamous cell carcinoma (Gasco et al, 2002a, b). The methylation of p16INK4A was less frequent than that of 14-3-3 $\sigma$ in ACC, but was infrequently detected both in these cancers at the same level (Figure 2A, B).

\section{Expression of 14-3-3 $\sigma$ in cultured-human SGC cells}

To confirm the result from the clinical materials, we examined the expression of 14-3-3 $\sigma$ in cultured-human SGC cells. By means of Northern (Figure 3A) and Western blotting (Figure 3B), downregulation of 14-3-3 $\sigma$ was detectable in two human ACC cell lines, ACCS and ACCY, and a neoplastic human salivary intercalated duct cell line, HSG, in comparison with a human salivary adenosquamous carcinoma cell line, TYS, and primary culturednormal salivary gland cells, SGs.

\section{Epigenetic change of 14-3-3 $\sigma$ gene in cultured-ACC cells}

In order to clarify the mechanism for the downregulation of 14-3-3 $\sigma$ in cultured-ACC cell lines, the methylation status of 14-3-3 $\sigma$ gene was assessed by the sequencing analysis after treatment with sodium bisulphite. As shown in Figure 4A, normal salivary gland cells, SG1, and a human adenosquamous carcinoma cell lines, TYS, showed no methylation in 14-3-3 $\sigma$ gene, and a neoplastic human salivary intercalated duct cell line, HSG, showed very limited hemimethylation pattern in 14-3-3 $\sigma$ gene. However, the ACC cell lines, ACCS and ACCY, carried widely hemimethylated 14-3-3 $\sigma$ DNA (Figure 4A). In the human fibrosarcoma cell line, HT1080 we used as positive control (Leffers et al, 1993), 14-3-3 gene was almost completely methylated (Figure 4A). We further confirmed the association between the methylation pattern and downregulation of 14-3-3 $\sigma$ by using a DNA demethylating agent, 5-aza-2'deoxycytidine. Treatment of ACCY cells with 5-aza-2'-deoxycytidine at $5 \mu \mathrm{m}$ clearly upregulated the 14-3-3 $\sigma$ mRNA and protein (Figure 4B, C).

\section{Impaired G2/M arrest in ACC cells}

As shown in Figure 5A and B, accumulation of the cells in the G2/ $\mathrm{M}$ phase and strong induction of the 14-3-3 $\sigma$ protein after irradiation were observed in the normal salivary gland cells, SG1. In contrast, irradiation did not induce the expression of 14-3-3 $\sigma$ and $\mathrm{G} 2 / \mathrm{M}$ arrest in ACCY cells, but markedly increased the cell population at the sub-G1 peak, indicating cell death.

\section{DISCUSSION}

In this study, we examined the expression of 14-3-3 $\sigma$ in the most common human SGCs, ACC and MEC. The findings obtained from 
A

ACC1 ACC2 ACC3 ACC4 ACC5 ACC6 ACC7 ACC8

$\overline{U M} \overline{U M} \overline{U M} \overline{U M} \overline{U M} \overline{U M} \overline{U M} \overline{U M}$



MEC1 MEC2 MEC3 MEC4 MEC5 MEC6 MEC7 MEC8 $\overline{U M} \overline{U M} \overline{U M} \overline{U M} \overline{U M} \overline{U M} \overline{U M} \overline{U M}$
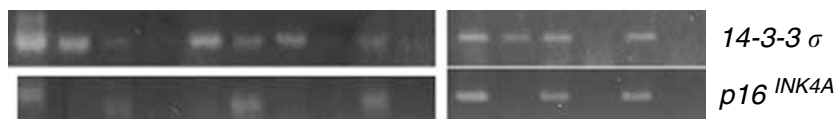

Posi. Nega.

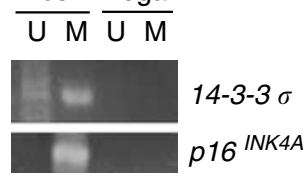

B

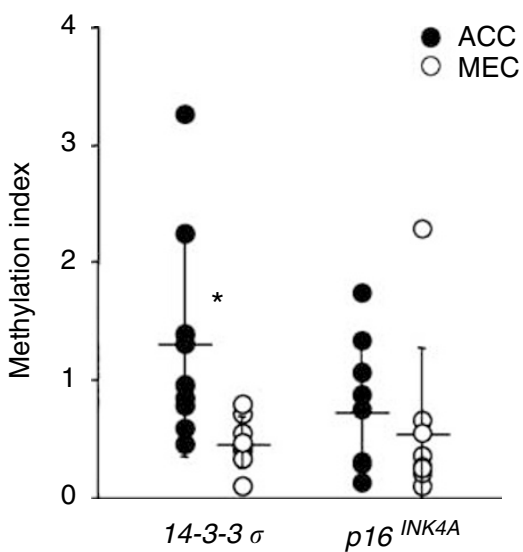

Figure 2 Methylation-specific PCR of the CpG island of the 14-3-3 $\sigma$ and $p / 6^{I N K 4 A}$ genes in ACC and MEC. (A) Microdissected tissues were subjected to MSP, and electrophoresis was performed in $4 \%$ agarose gels. The human fibrosarcoma cell line HTI080 was used as a positive control for methylated 14-3-3 $\sigma$. Normal salivary gland cells (SG) treated with Sssl methyltransferase were used as a positive control for $p / 6^{\text {INK } 4 A}$. Water was used as a negative control. (B) Methylation of the $14-3-3 \sigma$ and $p / 6^{\text {INK4A }}$ genes was semiquantitated by densitometric analysis. Methylation indices were calculated by dividing the density of the unmethylated allele into that of the methylated allele. Horizontal bars and vertical bars show mean and s.d., respectively. *Statistically significant by one-way ANOVA $(* P=0.0304)$

the present series of experiments are as follows. First, expression of 14-3-3 $\sigma$ was frequently lost in ACC, but not in MEC. Second, downregulation of 14-3-3 $\sigma$ in ACC was not due to the alteration of the p53 tumour suppressor protein, but rather to hypermethylation of the CpG islands of 14-3-3 $\sigma$ gene. Third, a cultured-ACC cell line, ACCY, also showed downregulation of 14-3-3 $\sigma$ and hypermethylation of the CpG islands of 14-3-3 $\sigma$ gene. Fourth, 14-3-3 $\sigma$ was not induced by irradiation in ACCY, and ACCY was very sensitive to the irradiation. These results suggest that downregulation of 14-3-3 $\sigma$ might be a critical event not only for the development of salivary gland ACC but also for the radiosensitivity of ACC cells.

Salivary gland ACCs are histologically divided into three groups: cribriform, tubular, and solid subtypes. Adenoid cystic carcinoma with solid subtypes has shown the worst prognosis. Stallmach et al (2002) reported that loss of heterozygosity at chromosome 6q23-
A
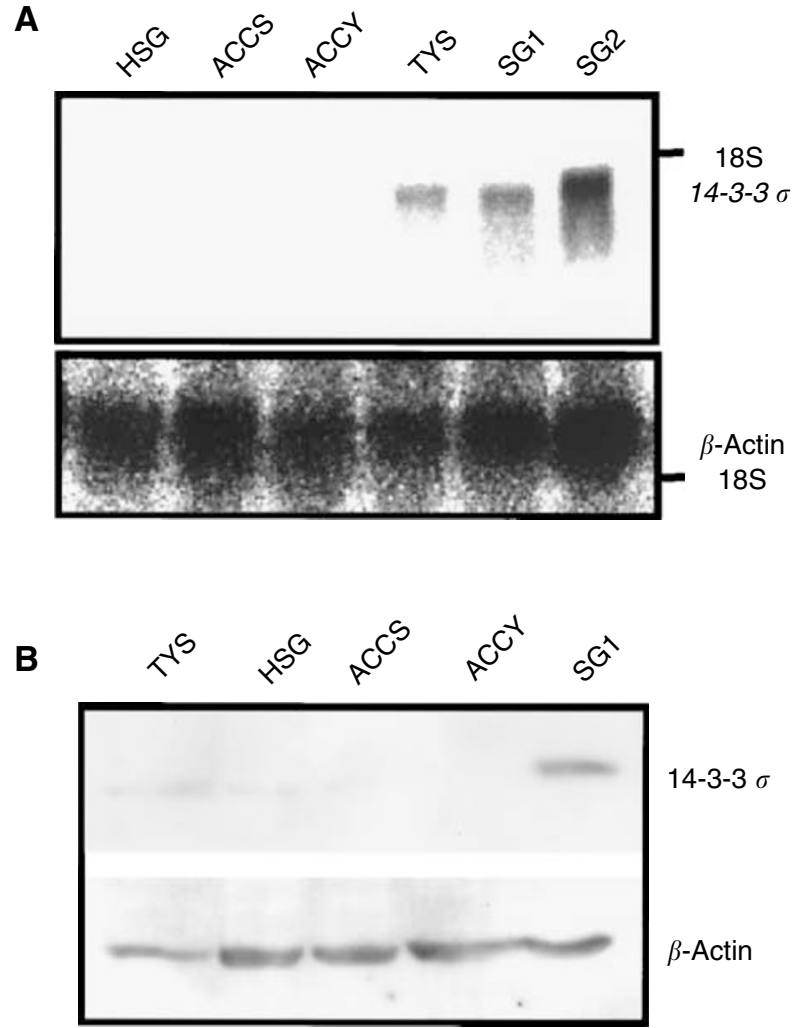

Figure 3 Expression of | 4-3-3 $\sigma$ in human SGC cells. (A) Detection of 1 4-3-3 $\sigma$ mRNA by Northern blot analysis. (B) Detection of 14-3-3 $\sigma$ protein by Western blot analysis.

25 was frequently found in the histological solid subtype of ACC. Yamamoto et al (1996) also demonstrated that the loss of heterozygosity in the $\mathrm{p} 53$ gene was higher in the solid subtype than in the cribriform subtype. In our present experiment, downregulation of 14-3-3 $\sigma$ frequently occurred in various subtypes of ACC, but not in MEC. In normal salivary gland, 143-3 $\sigma$ was highly expressed in duct cells and acinic cells but faintly in the myoepithelial cells. Mucoepidermoid carcinoma composed of the neoplastic epidermoid cells probably originated from precursor duct cells and of the neoplastic mucous producing cells, but most of the ACC are predominantly composed of the neoplastic myoepithelial cells. Thus, if the expression of 14-3-3 $\sigma$ might be downregulated even in the neoplastic myoepithelial cells, then the overall expression of 14-3-3 $\sigma$ in ACC was markedly limited.

It was reported that coincident epigenetic silencing of 14-3-3 $\sigma$ and $\mathrm{p} 16^{\mathrm{INK} 4 \mathrm{~A}}$ by methylation was an early event of carcinogenesis in oral cancers and vulval SCC (Gasco et al, 2002a, b). Moreover, downregulation of 14-3-3 $\sigma$ was reported to allow primary human keratinocyte to escape replicative senescence accompanied by downregulation of $\mathrm{p} 16^{\mathrm{INK} 4 \mathrm{~A}}$ (Dellambra et al, 2000). In our present study, we could detect frequent hypermethylation of 14-3-3 $\sigma$ gene in ACC, but not that of $p 16^{I N K 4 A}$ gene. However, three ACCs (ACC4, 6, 9), which have comparatively high methylation index of p16 ${ }^{\mathrm{INK} 4 \mathrm{~A}}$, showed histopathologically solid subtypes. Interestingly, Shintani et al (2000) have reported that $\mathrm{p} 16^{\mathrm{INK} 4 \mathrm{~A}}$ absent cases were the tumours with predominantly solid pattern by means of immunohistochemistry. Thus, in salivary gland ACC, downregulation of $\mathrm{p} 16^{\mathrm{INK} 4 \mathrm{~A}}$ might be critical event for the acquisition of histological subtype of ACC, and epigenetic silencing of 14-3-3 $\sigma$ was also considered to be an early event of carcinogenesis. Then, the genetic changes, such as $p 53$ mutation, may occur in the 
A

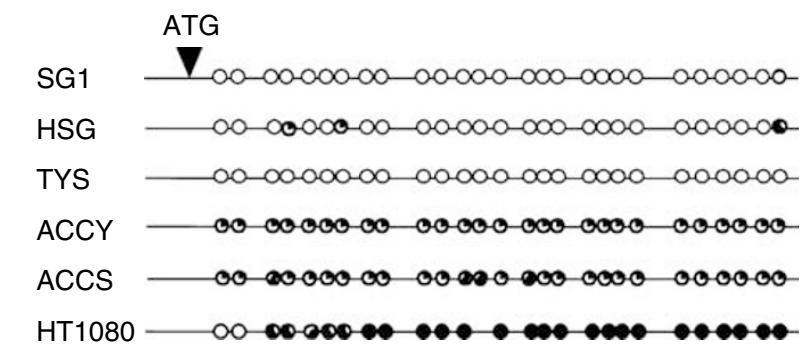

B

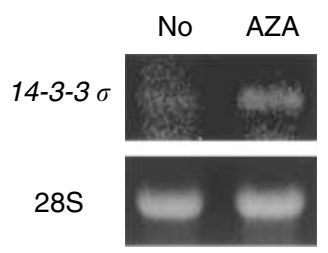

C

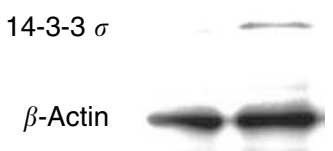

Figure 4 Methylation status of the 14-3-3 $\sigma$ gene in human SGC cells, (A) Sodium bisulphite sequencing of the 14-3-3 $\sigma$ CpG island. The methylated CpG sites are indicated by solid circles, and the unmethylated CpG sites are indicated by open circles. The cell lines examined are shown on the left. (B) Reactivation of 14-3-3 $\sigma$ mRNA in ACCY cells by treatment with 5-aza-2'-deoxycytidine for 3 days. RT-PCR was performed by use of specific primers for 14-3-3 $\sigma$. The 28S ribosomal RNA are shown below. (C) Reactivation of 14-3-3 $\sigma$ protein in ACCY cells by treatment with 5 -aza-2'-deoxycytidine for 5 days. Western blotting was performed by use of specific antibodies for 14-3-3 $\sigma$ and actin.

subsequent step on the salivary gland carcinogenesis. Osada et al (2002) demonstrated that small-cell lung cancer cell lines frequently showed DNA hypermethylation of 14-3-3 $\sigma$, but nonsmall-cell lung cancer cell lines did not. In our experiment, methylation pattern was quite different in the histological subtypes of SGCs, ACC, and MEC. Thus, methylation pattern of 14-3-3 $\sigma$ gene was highly affected by the originated cell type in the tumour.

14-3-3 $\sigma$ is known to be one of the target genes of the tumour suppressor p53 protein. Alterations in the $p 53$ gene have been frequently observed in various human carcinomas (Hollstein $e t a l$, 1991), and are considered to be one of the most critical genetic changes in the process of carcinogenesis. However, unlike other carcinomas reported previously, ACC and MEC showed relatively low rates of alteration of $p 53$ in the present study. Kiyoshima et al (2001) and Papadaki et al (1996) also reported low frequency of the alteration of $p 53$ gene in ACC and MEC. Thus, the downregulation of 14-3-3 $\sigma$ in ACC might not be due to the inactivation of p53 pathway, and inactivation of 14-3-3 $\sigma$ by methylation may lead to impairment of some of the functions of p53 as a 'gatekeeper'. Meanwhile, as shown in Table 1 and Figure 2, ACC3 showed downregulation of the 14-3-3 $\sigma$ protein, but no methylation of the gene was detectable. However, if ACC3 showed mutation in $p 53$ gene (Table 1), then downregulation of 14-3-3 $\sigma$ in ACC3 might be affected by the mutated $\mathrm{p} 53$.

Although most of ACC tissue simultaneously showed high methylation index of 14-3-3 $\sigma$ gene and downregulation of 14-3-3 $\sigma$ protein, some cases did not show the correlation between the methylation index and expression level of 14-3-3 $\sigma$. The reason for
A
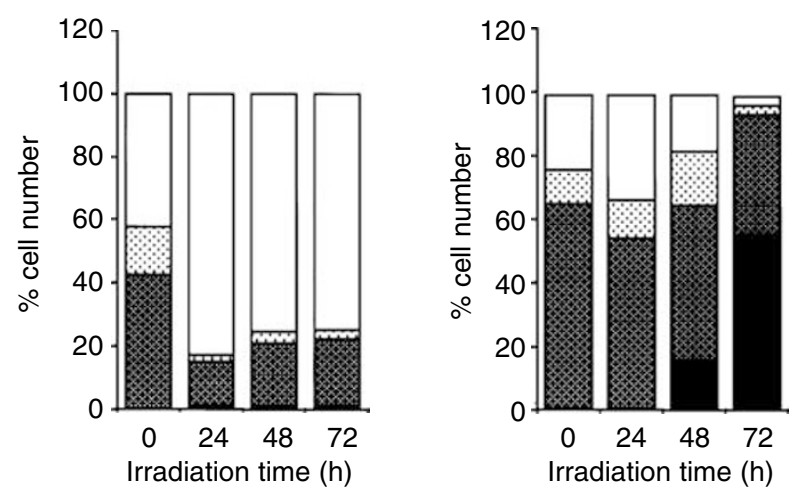

B

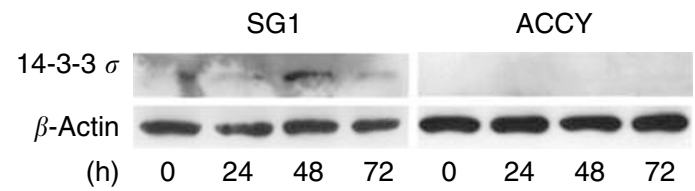

Figure 5 Cell cycle analysis of the SGC and normal cells after irradiation. (A) Cells were irradiated at $15 \mathrm{~Gy}$, then harvested at 24, 48, and $72 \mathrm{~h}$ after irradiation. After staining with Pl, cell cycles were analysed by flow cytometry. The populations of each phase are shown for the SGI cells (left) and ACC cells (right). (B) Expression of the 14-3-3 $\sigma$ protein after irradiation.

this discrepancy was unclear at present, however, it might be due to contamination of the stromal cells for analysis or the presence of another pre- or post-transcriptional regulation of 14-3-3 $\sigma$. Recently, Urano et al (2002) demonstrated that Efp, a RINGfinger-dependent ubiquitin ligase (E3) targeted proteolysis of 14-3$3 \sigma$. In SGC cells, proteolysis of 14-3-3 $\sigma$ by ubiquitin - proteasome pathway might contribute to regulate the level of 14-3-3 $\sigma$ protein.

Using cultured-SGC cells, we found the downregulation of 14-3$3 \sigma$ in ACC cell lines with hemimethylation of the 14-3-3 $\sigma$ gene, but mutational analysis showed that ACCY cells carried the mutant type p53 at Tyr126Stop (data not shown). Therefore, the downregulation of 14-3-3 $\sigma$ in ACCY cell lines was caused by the hemimethylation of 14-3-3 $\sigma$ gene and by the dysfunction of $\mathrm{p} 53$ pathway. Normal salivary gland cells, SG1, carried wild-type $p 53$ gene, and showed nonmethylation pattern of 14-3-3 $\sigma$ gene and high expression of 14-3-3 $\sigma$ mRNA and protein. DNA damage induced by the irradiation enhanced the expression of 14-3-3 $\sigma$ protein in SG1 cells. These results indicated that expression of 143-3 $\sigma$ in normal salivary gland cells was regulated by the activated p53 on the nonmethylated 14-3-3 $\sigma$ gene. HSG and TYS cells that were reported to carry mutant type p53 at Asn30Ser and Asp281His, respectively (Shinagawa et al, 2003). HSG and TYS cells showed different expression patterns of 14-3-3 $\sigma$. Shinagawa et al (2003) also reported that DNA-damaging chemotherapeutic drugs did not activate any reporter plasmids containing the promoter sequence of p53 target genes (p21waf1, BAX, MDM2, p53AIP1, or PUMA) in HSG cells, but activated only the p21waf1 promoter in TYS cells. Thus, mutated p53 in TYS cells, but not the mutated p53 in HSG cells, might affect the expression of 14-3-3 $\sigma$.

The 14-3-3 $\sigma$ gene has been reported to be a G2 checkpoint control gene. Since 14-3-3 $\sigma(-/-)$ cells are defective in their maintenance of G2 arrest, they enter M phase without repair of the aberrant chromosome structures and undergo cell death during mitosis (Chan et al, 1999). In the present experiment, apparent G2/ 
$\mathrm{M}$ arrest was induced in normal salivary gland cells by irradiation; however, G2/M arrest was not induced by irradiation in the ACCY cells. Moreover, 14-3-3 $\sigma$ was induced in normal salivary glands by irradiation, while 14-3-3 $\sigma$ was not induced in ACCY cells. Although the affect of factors other than 14-3-3 $\sigma$ could be considered, this fragility to the irradiation in ACC cells is in agreement with the clinical observations described previously (Simpson et al, 1984; Vikram et al, 1984; Miglianico et al, 1987; Garden et al, 1995; Parsons et al, 1996). These results indicate that DNA-damaging therapy might be more effective in cancers, such as ACC, with hypermethylation of 14-3-3 $\sigma$ gene than in cancers, such as MEC, without hypermethylation of 14-3-3 $\sigma$ gene.

In conclusion, our findings, that $14-3-3 \sigma$ is frequently downregulated in ACC, provide a new possible mechanism in understanding the mechanism of salivary gland carcinogenesis.

\section{REFERENCES}

Ajiki W, Kinoshita N, Tsukuma H, Oshima A, Research Group For Population-Based Cancer Registration in Japan (2001) Cancer incidence and incidence rates in Japan in 1996: estimates based on data from 10 population-based cancer registries. Jpn J Clin Oncol 31: 410-414

Batsakis JG (1979) Tumors of the Head and Neck: Clinical and Pathological Considerations, 2nd edn. Baltimore: Williams and Wilkins

Bensadoun RJ, Blanc-Vincent MP, Chauvel P, Dassonville O, GoryDelabaere G, Demard F (2001) Malignant tumours of the salivary glands. Br J Cancer 84(Suppl 2): $42-48$

Chan TA, Hermeking H, Langauer C, Kinzler KW, Vogelstein B (1999) 143-3 sigma is required to prevent mitotic catastrophe after DNA damage. Nature 401: 616-620

Dellambra E, Golisano O, Bondanza S, Siviero E, Lacal P, Molinari M, D'Atri S, De Luca M (2000) Downregulation of 14-3-3 sigma prevents clonal evolution and leads to immortalization of primary human keratinocytes. J Cell Biol 149: 1117-1130

Ferguson AT, Evron E, Umbricht CB, Pandita TK, Chan TA, Hermeking H, Marks JR, Lambers AR, Futreal PA, Stampfer MR, Sukumar S (2000) High frequency of hypermethylation at the 14-3-3 sigma locus leads to gene silencing in breast cancer. Proc Natl Acad Sci USA 97: 6049-6054

Garden AS, Weber RS, Morrison WH, Ang KK, Peters LJ (1995) The influence of positive margins and nerve invasion in adenoid cystic carcinoma of the head and neck treated with surgery and radiation. Int $J$ Radiat Oncol Biol Phys 32: 619-626

Gasco M, Bell AK, Heath V, Sullivan A, Smith P, Hiller L, Yulug I, Numico G, Merlano M, Farrell PJ, Tavassoli M, Gusterson B, Crook T (2002a) Epigenetic inactivation of 14-3-3 sigma in oral carcinoma: association with p16(INK4a) silencing and human papillomavirus negativity. Cancer Res 62: $2072-2076$

Gasco M, Sullivan A, Repellin C, Brooks L, Farrell PJ, Tidy JA, Dunne B, Gusterson B, Evans DJ, Crook T (2002b) Coincident inactivation of 14-33 sigma and p16INK4a is an early event in vulval squamous neoplasia. Oncogene 21: $1876-1881$

Grenman R, Pekkola-Heino K, Joensuu H, Aitasalo K, Klemi P, Lakkala T (1992) UT-MUC-1, a new mucoepidermoid carcinoma cell line, and its radiosensitivity. Arch Otolaryngol Head Neck Surg 118: 542-547

Herman JG, Graff JR, Myohanen S, Nelkin BD, Baylin SB (1996) Methylation-specific PCR: a novel PCR assay for methylation status of CpG islands. Proc Natl Acad Sci USA 93: $9821-9826$

Hermeking $\mathrm{H}$, Lengauer $\mathrm{C}$, Polyak K, He TC, Zhang L, Thiagalingam S, Kinzler KW, Vogelstein B (1997) 14-3-3 sigma is a p53-regulated inhibitor of G2/M progression. Mol Cell 1: 3-11

Hollstein M, Sidransky D, Vogelstein B, Harris CC (1991) p53 mutations in human cancers. Science 253: 49-53

Iwata N, Yamamoto H, Sasaki S, Itoh F, Suzuki H, Kikuchi T, Kaneto H, Iku S, Ozeki I, Karino Y, Satoh T, Toyota J, Satoh M, Endo T, Imai K (2000) Frequent hypermethylation of $\mathrm{CpG}$ islands and loss of expression of the 14-3-3 sigma gene in human hepatocellular carcinoma. Oncogene 19: $5298-5302$

Kawamata H, Nakashiro K, Uchida D, Hino S, Omotehara F, Yoshida H, Sato M (1998) Induction of TSC-22 by treatment with a new anti-cancer drug, vesnarinone, in a human salivary gland cancer cell. Br J Cancer 77: $71-78$
Furthermore, our results also indicate that DNA-damaging therapy might be effective in SGCs with hypermethylation of 14-3-3 $\sigma$ gene. Downregulation of 14-3-3 $\sigma$ could be useful as a predictive marker for the radiosensitivity of SGC, and the combination of 14-3-3 $\sigma$ blockade and radiotherapy could constitute a new therapeutic approach for radioresistant SGC, particularly for MEC.

\section{ACKNOWLEDGEMENTS}

We thank Drs Naozumi Ishimaru and Yoshio Hayashi (Department of Pathology, Tokushima University School of Dentistry) for their valuable histopathologic advice. This study was supported in part by a grant-in-aid from the Ministry of Education, Science and Culture of Japan.
Kiyoshima T, Shima K, Kobayashi I, Matsuo K, Okamura K, Komatsu S, Rasul AM, Sakai H (2001) Expression of p53 tumor suppressor gene in adenoid cystic and mucoepidermoid carcinomas of the salivary glands. Oral Oncol 37: $315-322$

Le QT, Birdwell S, Terris DJ, Gabalski EC, Varghese A, Fee Jr W, Goffinet DR (1999) Postoperative irradiation of minor salivary gland malignancies of the head and neck. Radiother Oncol 52: 165-171

Leffers H, Madsen P, Rasmussen HH, Honore B, Andersen AH, Walbum E, Vandekerckhove J, Celis JE (1993) Molecular cloning and expression of the transformation sensitive epithelial marker stratifin. A member of a protein family that has been involved in the protein kinase $\mathrm{C}$ signalling pathway. J Mol Biol 231: $982-998$

Miglianico L, Eshwege F, Marandas P, Wibault P (1987) Cervico-facial adenoid cystic carcinoma: study of 102 cases. Influence of radiation therapy. Int J Radiat Oncol Biol Phys 13: 673-678

Nascimento AG, Amaral LP, Prado LA, Kligerman J, Silveira TR (1986) Mucoepidermoid carcinoma of salivary glands: a clinicopathologic study of 46 cases. Head Neck Surg 8: $409-417$

Osada H, Tatematsu Y, Yatabe Y, Nakagawa T, Konishi H, Harano T, Tezel E, Takada M, Takahashi T (2002) Frequent and histological typespecific inactivation of 14-3-3 sigma in human lung cancers. Oncogene 21: $2418-2424$

Papadaki H, Finkelstein SD, Kounelis S, Bakker A, Swalsky PA, Kapadia SB (1996) The role of $\mathrm{p} 53$ mutation and protein expression in primary and recurrent adenoid cystic carcinoma. Hum Pathol 27: $567-572$

Parsons JT, Mendenhall WM, Stringer SP, Cassisi NJ, Million RR (1996) Management of minor salivary gland carcinomas. Int J Radiat Oncol Biol Phys 35: $443-454$

Pinkston JA, Cole P (1999) Incidence rates of salivary gland tumours: results from a population based study. Otolaryngol Head Neck Surg 120: $834-840$

Rocco JW, Sidransky D (2001) p16(MTS-1/CDKN2/INK4a) in cancer progression. Exp Cell Res 264: 42-55

Seifert G, Sobin LH (1992) The World Health Organization's histological classification of salivary gland tumors: a commentary on the Second Edition. Cancer 70: 379-385

Shinagawa Y, Kawamata H, Omotehara F, Nakashiro K, Hoque MO, Furihata T, Horiuchi H, Imai Y, Fujimori T, Fujibayashi T (2003) Evaluation of the chemosensitivity of head and neck cancer cells based on the diverse function of mutated-p53. Int J Oncol 22: 383-389

Shintani S, Mihara M, Nakahara Y, Kiyota A, Yoshihama Y, Ueyama Y, Matsumura $\mathrm{T}$ (2000) Infrequent alternations of $\mathrm{RB}$ pathway (Rbp16INK4A-cyclinD1) in adenoid cystic carcinoma of salivary glands. Anticancer Res 20: 2169-2175

Shirasuna K, Sato M, Miyazaki T (1981) A neoplastic epithelial duct cell line established from an irradiated human salivary gland. Cancer 48: 745-752

Shirasuna K, Watatani K, Furusawa H, Saka M, Morioka S, Yoshioka H, Matsuya T (1990) Biological characterization of pseudocyst-forming cell lines from human adenoid cystic carcinomas of minor salivary gland origin. Cancer Res 50: 4139-4145

Simpson JR, Thawley SE, Matsuba HM (1984) Adenoid cystic salivary gland carcinoma: treatment with irradiation and surgery. Radiology 151: $509-512$ 
Speight PM, Barrett AW (2002) Salivary gland tumours. Oral Dis 8: $229-240$

Stallmach I, Zenklusen P, Komminoth P, Schmid S, Perren A, Roos M, Jianming Z, Heitz PU, Pfaltz M (2002) Loss of heterozygosity at chromosome 6q23-25 correlates with clinical and histologic parameters in salivary gland adenoid cystic carcinoma. Virchows Arch 440: 77-84

Suzuki H, Itoh F, Toyota M, Kikuchi T, Kakiuchi H, Imai K (2000) Inactivation of the 14-3-3 sigma gene is associated with $5^{\prime} \mathrm{CpG}$ island hypermethylation in human cancers. Cancer Res 60: 4353-4357

Tsubochi H, Suzuki T, Suzuki S, Ohashi Y, Ishibashi S, Moriya T, Fujimura S, Sasano H (2000) Immunohistochemical study of basaloid squamous cell carcinoma, adenoid cystic and mucoepidermoid carcinoma in the upper aerodigestive tract. Anticancer Res 20: 1205-1211
Urano T, Saito T, Tsukui T, Fujita M, Hosoi T, Muramatsu M, Ouchi Y, Inoue S (2002) Efp targets 14-3-3 sigma for proteolysis and promotes breast tumour growth. Nature 417: 871-875

Vikram B, Strong EW, Shah JP, Spiro RH (1984) Radiation therapy in adenoid cystic carcinoma. Int J Radiat Oncol Biol Phys 10: 221-223

Yamamoto Y, Virmani AK, Wistuba II, McIntire D, Vuitch F, AlboresSaavedra J, Gazdar AF (1996) Loss of heterozygosity and microsatellite alterations in p53 and RB genes in adenoid cystic carcinoma of the salivary glands. Hum Pathol 27: 1204-1210

Yanagawa T, Hayashi Y, Yoshida H, Yura Y, Nagamine S, Bando T, Sato M (1986) An adenoid squamous carcinoma-forming cell line established from an oral keratinizing squamous cell carcinoma expressing carcinoembryonic antigen. Am J Pathol 124: 496-509 